\title{
Articles
}

\section{Reflecting on different worlds: How experiential knowledge from learning Japanese has informed the teaching practice of ELT teachers}

\section{Peter Burden}

\section{Okayama Shoka University}

Deliberating on and analyzing ideas about teaching can lead to an improvement in our teaching practice. By taking a reflexive stance, we can thoughtfully grapple with issues of theory-practice dichotomy. Cognitive "received knowledge" from books or teacher training, and emotional "experiential knowledge" which can come from participating in language learning often do not "gel" and this is manifested in tensions in practice. Classroom learning experience can feed back into received knowledge to develop classroom practice, so an interest in where one's teaching knowledge comes from can lead to a better understanding of practice. Through interviews, six university English teachers who are studying or have formally studied Japanese reflected on their experiences as learners and how those experiences have informed their teaching practices. Results show that although situated in different contexts and settings, the participants are not fixed upon any one method and that self-understanding emerges through engagement and reconsidering received knowledge to gain new perspectives on classroom reality.

教育方法について振り返り、考えをさまざまな角度から分析してみるというのは指導実践を向 上させるのに大変役に立つ。このような内省的なアプローチを取ることにより、理論と実践が乘 離していることが理解できる。本や研修会などを通して得た認知レベルの知識と、自らが外国語 を学んだ情意的な経験とが結びつかないことが多く、そのため教室で指導している際にどちら

JALT Journal, Vol. 29, No. 2, November, 2007 
を優先すればよいのかについて悩むことにもなる。このような問題を解決するためには、自らの 外国語の学習体験を振り返りかつ深く内省することが助けとなる。これが延いては学習者の指 導にも役立つ。指導に関する知識はどこから得たものなのかを振り返ってみることにより現在の 指導方法を向上させることができるであろう。本研究では現在大学で英語教育を行っている教 員 6 名に面接調査を行い、過去の日本語学習の経験が現在の指導法にどのように影響している かを探った。結果の示すところ、それぞれ教育活動を行っている環境や状況は異なっているが、 だれも特定のひとつの教授法を使っているということはないという傾向がどの教員にも共通して 見られた。また、自分が実際にどのような指導を行っているかを振り返り、すでにもつている知識 を自分の指導に照らし合わせて内省することにより、はじめて確固たる知識がえられるというこ とがわかった。

7 his article focuses on how teachers' personal experiences of learning Japanese in a formal class have influenced their practical or experiential knowledge of teaching EFL in a Japanese university. While it is claimed that teachers' own experiences as language learners and their beliefs about teachers and teaching are often a reflection of how they themselves were taught (Richards \& Lockhart, 1994), this study proposes that considering teachers' experiences of learning Japanese and how these experiences have led to reflection on their teaching can suggest avenues for improvement. Through reflecting on learning experiences, change in teaching practice is encouraged through a developmental spiral of deliberating on and analyzing ideas about teaching and how language learning has occurred (Thornbury, 1991). Flowerdew (1998) suggests that reflecting on foreign language learning develops insights into the language learning process, encourages analysis and adaptation of one's own learning strategies, and leads to a reevaluation of theory in the light of learning experiences. In my own experiences of learning Japanese, I became aware that I enjoyed and valued activities that as a "communicative" language teacher I had been discouraging in my own "conversation" classroom. This dissonance led me to question my own teaching practice in terms of "tensions" (Freeman, 1993, p. 488) or doubt, hesitancy, or perplexity (Dewey, 1933). The questioning encouraged critical reflection on, and the renegotiation of, my ideas about teaching and learning. When referring to a "post-method condition," Kumaravadivelu (2006, p. 69) argues that renegotiation of practical knowledge "rupture[s] the reified role relationship between theorizers and practitioners" by encouraging teachers to theorize from their practice and conversely to practice what they theorize to improve teaching. And that is what happened to me. Trying to reconcile my critical reflections with what I knew as a teacher and my experiences as a learner ultimately led me to conduct 
this study. As teachers learn to understand and change their work behavior by continually examining, analyzing, hypothesizing, theorizing, and reflecting as they work (Schön, 1983), this study focuses on teachers' personal experiences learning language and how they can be applied to teaching language.

While evaluation has been defined as a "systematic collection and analysis of all relevant information necessary to promote the improvement of the curriculum and to assess its effectiveness within the context of the particular institution" (Brown, 1995, p. 24), to encourage teacher growth, the context of teachers' reflection, a receptiveness to alternative perspectives, and being aware of unspoken assumptions need to be built into a school's evaluation system (Brandt, 2007). Teachers' personal and reflective knowledge, including personal beliefs and principles and their capacity to reflect upon and assess their performance, enables them to make decisions about how best to approach practice (Cooper \& McIntyre, 1996). Underpinning this study is the view that teachers' orientations to new knowledge may be shaped and organized through personal experience. As teaching is a knowledge-based activity or a process where "ideas are sown, germinated, thinned, pruned, and displayed" (Hegarty, 2000, p. 454), teachers need to reflect on received knowledge in the light of their classroom experience, thus creating conditions where the experience can become learned knowledge. McDonough (2002, p. 406) suggests that language learning experiences (LLE) encourage perspectives that "are quite discrepant, even dissonant" from the perspectives of the "teacherpersona" (p. 407). Strong emotions, both positive and negative, generated from foreign language instruction suggest that "power, authority, and legitimacy" (Nespor, 1987, p. 320) come from Japanese classroom learning as "critical episodes." Nespor proposes that episodes derived from personal experience create "experiential knowledge" which is embodied and reconstructed out of narratives of a teacher's life (Clandinin \& Connelly, 1987, p. 487). The aim of the study is to understand teachers' thoughts about whether their learning of Japanese has served as a basis for critical reflection about teaching and if so, how.

\section{Where Does Teaching Knowledge Come From?}

Our knowledge of teaching is characterized by a discrepancy between facts, data, and theory, or a body of knowledge produced by academia (received knowledge), and practical action, experience, and conceptual frameworks (experiential knowledge) (see Elbaz, 1981; Eraut, 1994; Flow- 
erdew, 1998; Golombek, 1998; Griffiths \& Tann, 1992; Wallace, 1991; Williams, 1999). Wallace (1991) argues that received knowledge should both directly inform the experiential knowledge element and be directly informed by it. Thus, experiential knowledge is enriched when it has input from received knowledge (Flowerdew, 1998), while received knowledge may be better assimilated when learned through experience. As students of language, teachers-as-learners are beneficiaries of teacher efforts seeing the teacher "front stage and center like an audience viewing a play" (Lortie, 1975, p. 62). Although not "privy to the teacher's private intentions and personal reflections on classroom events" (p. 62) the learner can place the teacher's actions within a pedagogically-oriented framework which Lortie calls an "apprenticeship of observation" (p. 61).

In addition, Calderhead and Robson (1991, pp. 1-4) argue that observing teachers "leads to the development of a body of values, commitments, orientations, and practices," often through images in the form of "memorized snapshots." These images of classroom lessons or incidents help teachers to interpret and solve teaching problems. These images can be "episodic memories" of past learning experiences and invariably are either positive or negative. Not only as teachers, but also as thinking beings, we develop contextually specific theories of effective social practice that are grounded in reflection. Teachers reflect on their own experiences and summarize their episodic memories taken from classroom experience. As students of Japanese as a second or foreign language, teachers also hold images of good teachers and their practices which are easy to recall and remember; such teachers are said to serve as role models. Drawing on these images of "good teaching" experienced in Japanese classes, and linking the positive images to their own personality attributes, reinforces the images of the kind of teacher one wants to become. As Eraut (1994) notes, knowledge may be acquired from learning experiences:

People tend to teach, or in a few cases avoid teaching, in a manner similar to that in which they have been taught. Their reflection on their own experience in schooling and other life aspects will have contributed to their knowledge of people and theories of human behavior. (p. 71)

\section{Reflecting on Two Worlds}

Studies on language learning experience (LLE) courses in which teachers learn a language that is new to them from the beginner level are 
not new (Golebiowska, 1985; Lowe, 1987; McDonough, 2002; Ransdell, 1993; Waters, Sunderland, Bray, \& Allwright, 1990). Accounts of such courses have focused on the value of reflection on the LLEs as a means of gaining insights into the participants' future students' learning processes and thereby, ultimately, informing their approaches to teaching. Richards and Lockhart (1994, p. 3) note that "the teacher who has a more extensive knowledge and deeper awareness about the different components and dimensions of teaching is better prepared to make appropriate judgments and decisions in teaching." Being on the receiving end of a lesson allows teachers to see connections between the learning of their target language as learners and the learning of the language they teach and helps them to become more sensitive to problems and processes confronting learners, and thereby encourages them to look at some of their professional preconceptions. The above studies generally suggest that teachers should explore their ideas, as the more open-minded one is, the better a teacher one becomes.

\section{Methods}

\section{Research Questions}

Through this study I sought to understand other teachers' experiences of studying Japanese formally in a classroom. After hearing about each teacher's length of time learning Japanese formally, their perceived level, and to what degree they had pursued professional EFL qualifications, I encouraged the participants to consider the following questions developed from my own personal language learning experiences and enhanced through readings on how teachers construct their professional knowledge base:

1) How has studying Japanese formally in a classroom influenced the way participants teach?

2) What positive influences have language learning experiences (LLE) had on their teaching approach?

3) What negative aspects of LLE have fed into their teaching approach?

4) What positive or negative images do participants hold of their Japanese language teachers?

One perspective is that knowledge is constructed, built on previous experience, coupled with experience, and is transforming, evolving, and con- 
sequential (Harrington, 1994), so another aim of the study was to listen to teachers describe how they understand the worlds in which they live and work in a real-life context. I intended to generate self-understanding in both the participants and myself through an engagement with the interview questions.

\section{Participants}

All six participants in this study were employed as "native" speakers at a former National University in western Japan. Table 1 and the Appendix outline the details of the six participants, all male, who range in age from their early 30 s to their early 50s. While each teacher had classroom autonomy, they were expected to comply with a common overarching theme-based approach that was written into the syllabus. Different topics were introduced weekly while students were encouraged to practice their speaking and listening skills, focusing on the topics to improve their conversational abilities.

The participants all appeared highly qualified; four hold doctorates in EFL-related fields or were studying for one part-time or through distance learning, while the other two participants were studying for their master's degrees through distance (extension) learning at the time of the interviews. John is the only participant whose research field is not education. They had all formally studied Japanese and admitted only partial feelings of success; only one participant, Nick, was still studying in a class at the time of the interviews. Pat, who had studied Japanese almost daily as a minor subject in his undergraduate degree in the U.S.A. and studied Japanese intensively in class for the proficiency exam in Japan, has the most experience. On the other hand, Tom had only studied once a week in a class at a community college prior to coming to Japan and "for about a month" on Saturdays at his local community center. Although the contexts and settings of learning Japanese and teaching English were different, they did have some commonalities all of which lends interest to how the participants' teaching has been shaped by their unique experiences.

\section{Procedure}

Semistructured interviews with six teachers who were studying or had recently studied Japanese while teaching English in a Japanese university context were used to elicit information about these teachers' knowledge, 
Table 1. Participants in the interviews

\begin{tabular}{|c|c|c|c|c|c|c|}
\hline Name & Nationality & Age & $\begin{array}{l}\text { Length } \\
\text { of time } \\
\text { teaching } \\
\text { English } \\
\text { in Japan }\end{array}$ & $\begin{array}{l}\text { Length } \\
\text { of time } \\
\text { studying } \\
\text { in a } \\
\text { Japanese } \\
\text { class }\end{array}$ & $\begin{array}{l}\text { Japanese } \\
\text { level as the } \\
\text { participants } \\
\text { see it }\end{array}$ & $\begin{array}{l}\text { Professional } \\
\text { qualifications }\end{array}$ \\
\hline Bill & American & 35 & 12 years & $\begin{array}{l}3 \text { or } 4 \\
\text { years, } \\
\text { once a } \\
\text { week }\end{array}$ & $\begin{array}{l}\text { Intermedi- } \\
\text { ate/ Upper } \\
\text { intermediate }\end{array}$ & $\begin{array}{c}\text { MA in } \\
\text { Applied } \\
\text { Linguistics } \\
\text { PhD research }\end{array}$ \\
\hline Nick & British & 44 & 13 years & $\begin{array}{l}3 \text { or } 4 \\
\text { years }\end{array}$ & $\begin{array}{l}\text { Pre-interme- } \\
\text { diate }\end{array}$ & $\begin{array}{c}\text { MA in } \\
\text { Applied } \\
\text { Linguistics } \\
\text { EdD in TESOL }\end{array}$ \\
\hline Alex & Canadian & $\begin{array}{l}\text { Early } \\
40 \mathrm{~s}\end{array}$ & 12 years & 3 years & Intermediate & $\begin{array}{c}\text { DELTA } \\
\text { MA in Ap- } \\
\text { plied linguis- } \\
\text { tics research }\end{array}$ \\
\hline Tom & American & 53 & 20 years & 1 year & $\begin{array}{l}\text { Pre-interme- } \\
\text { diate }\end{array}$ & $\begin{array}{l}\text { MA in TESOL } \\
\text { PhD research }\end{array}$ \\
\hline Pat & American & 33 & 10 years & $\begin{array}{l}4 \text { years } \\
\text { full time }\end{array}$ & $\begin{array}{l}\text { "Failed } \\
\text { Level } 1 \text { of } \\
\text { the Japanese } \\
\text { language } \\
\text { proficiency } \\
\text { test by } 25 \\
\text { points" }\end{array}$ & $\begin{array}{l}\text { MA in TESOL } \\
\text { EdD in TESOL } \\
\text { research }\end{array}$ \\
\hline John & Australian & 44 & 12 years & $\begin{array}{l}3 \text { years } \\
\text { as an } \\
\text { external } \\
\text { student }\end{array}$ & $\begin{array}{c}\text { "Poor, } \\
\text { considering } \\
\text { the length } \\
\text { of time I } \\
\text { have been in } \\
\text { Japan" }\end{array}$ & $\begin{array}{l}\text { MA in De- } \\
\text { fense Studies }\end{array}$ \\
\hline
\end{tabular}

attitudes, and values. The participants, who volunteered their time, had expressed interest in the project and interviews took place at a location of each participant's choice. I decided to interview ELT teachers to explore perspectives and shared meanings in order to develop insights (Wellington, 2000) by encouraging dialogue while emphasizing the uniqueness of 
each individual's experience. Although each interview progressed down its own path according to the direction of the responses, the interviews all conatined a set of guiding questions based on the four research questions.

After conditions of confidentiality were agreed upon, each participant was interviewed once for around an hour and the interview data were transcribed verbatim and returned. Participants were encouraged to email me if they had new insights upon reflection; the interview, checking the transcripts, and sending follow-up emails all were aimed at encouraging reflective engagement and self-understanding.

\section{Method of Analysis}

Following transcription, the transcripts were analyzed for common themes, categories, and subcategories. Data were coded and collapsed by considering the main overall common categories or common, overarching themes and then the variants, which became subcategories. The underlying structures and recurring themes of the interviews meant that categorization was reasonably straightforward as the "constant comparative method" (Lincoln \& Guba, 1985) was followed. Following this method, responses to the interview questions were categorized and written on cards which were constantly compared for overlapping themes or different nuances of meaning. Each card was reviewed to be certain that inclusion in the category was justified and if a new category was discovered, or the connection was "fuzzy" (Wolcott, 1994), all the other cards were reanalyzed to see if they possessed common characteristics with the new categories. The themes were addressed in terms of the specific questions of the study, with respect to such questions as "what does this statement tell me about the influence of Japanese classes on the participant's practice?" Subsequently the nonredundant themes were collected into a description. For example, under the over-arching theme of how language-learning experiences have influenced participants' teaching practice, four subcategories emerged from the data: a sense of empathy, making learning more meaningful, power, and encouragement. I will discuss the themes in turn in the next section.

\section{Findings}

All of the teachers in this small study have shown how their experiential knowledge of learning Japanese has informed their practice, guiding their sense-making processes and filtering experience so as to reconstruct 
knowledge and respond to the exigencies of a teaching situation. All of the teachers were very supportive and were intrigued as they had not considered that their limited Japanese learning could contribute to their English teaching practice. One overall finding is that participants saw learning as a more individualized process where learners "invest" (Donato, 2000, p. 44) their own goals and beliefs in activities. Reflecting on experience as individual learners, the participants claimed to know what "does not work" for them, but, as Pat suggested, they "try to figure out ways that in [their] own way are good." Each participant, like every language learner, had unique learning preferences and ways they approached tasks. Reflecting on experience, alongside an emphasis on an explicit task rationale over inductive learning, using activities and techniques that they saw as beneficial, led them to encourage learner autonomy. Pat suggested that he understands "what it takes" to become good at a language, so to his students he emphasizes "trying" and encourages autonomy as "what you put in is what you'll get out."

\section{How Language Learning Experiences (LLE) Have Influenced Participants' Teaching Practice}

\section{A Sense of Empathy}

All of the participants emphasized heightened feelings of empathy similar to Ransdell (1993, p. 42) who benefited from recalling his own "sweaty palms and choked throat" which led him to be more patient and encouraging with his own perspiring students. Bill observed that classroom learning "put me back into the seat as a student, and gave me that perspective from the students' viewpoint," so he became more patient and encouraging with his own tense students. His concurrent master's degree study in applied linguistics was giving him a chance to participate in a language class that created a meaningful context to apply, and to crucially reflect on, his received knowledge from his course. As a result, he felt he was:
...better equipped to critically apply-and to some extent reinforce- what I believed, but studying Japanese put me back into the seat as a student, and gave me a chance to look at the class from a student's perspective which I hadn't done for a very long time.

Bill and Pat voiced a sense of satisfaction, Alex shared particular experiences to convey his feelings and concerns, and Nick professed to see "certain validity" in being a language teacher. He stated that he expresses 
this validity in how he "presents" language: "I believe that I'm not just bullshitting the students. You know you're not just telling them to do things that you're not prepared to do yourself." In other words, he insists that his day-to-day classroom activity is consciously borne out of his own experience. While Bill admits to only "partial success" in his Japanese, he feels he imparts the necessity of motivation and "finding your own way," and similarly, Tom and John admired their students' perseverance and respected their accomplishments, again in the light of their own perceived poor learning.

\section{Making Learning more Meaningful}

After reflecting on classroom learning, participants all claim to have gained insight into the language learning process. Pat says he avoids blandishments such as "just try and speak the language" or "don't worry about mistakes," which he sees as liable to frustrate individual learning styles. Bill now always explains the strategies he is encouraging his students to use, complementing his own "received knowledge." While he feels he is "supposed to encourage [tolerance of] ambiguity and [tell students] not to worry if [they] don't know a word" he said he realized that students who are not used to reading strategies can be as disconcerted as he was in Japanese class when he felt that each overlooked word in a text was a lost learning opportunity. Tom similarly expressed concern that teachers just "pass out the wisdom" without explaining task rationale, so he now makes sure students understand task rationale. Both Nick and Pat stated that they encourage what they say are good study habits and strategies and skills but worry that received knowledge is too abstract to transmit to students and so try to convince the students by illustrating how completing such a task would be beneficial to their own learning. They now encourage a learner-centered bottom-up interpretations of the classroom instead of a top-down planning perspective (McDonough, 2002), as learners have their own ways of approaching their language learning.

\section{Power}

LLE provides a point of reference where participants test out the discrepancy between their teacher and learner selves. Nick suggests this encourages empathy because, as a teacher, he has a lot of power so he "could basically dictate what goes on more or less, although [he] now strongly believe[s] in giving students as much autonomy as possible." 
Alex also recalled the insecurity he felt as a student and said that he now tries to give each student a sense of achievement by acknowledging the effort each student makes and emphasizing a more social, interactional, teacher/student relationship to individualize learning. As Waters et al. (1990) note, LLE can "provide participants with an opportunity to reflect on the nature of language learning from the learner's perspective...it acts as a forcible catalyst for speeding the transition from a teacher-centered to a more learner-centered view of classroom events" (p. 306). Nick concurred, saying that he could see the discrepancy between his teacher and learner selves because sitting on the other side of a desk as a learner allowed him to witness the mechanics of being a teacher and gave him pause to ponder: "What would I do in that situation?" Nick and Tom became aware of how much power teachers have and how they manage the learning while realizing how little power they possessed as learners. Thus, reflecting on learning experiences and the inbuilt power relationship encourages an "interpretive framework" (Golombek, 1998, p. 459), so that teachers can make sense of their teaching situations through recounting their experiences and making experiential knowledge explicit.

\section{Encouragement}

Recalling their experiences, Nick and Alex try to encourage a nonthreatening learning atmosphere which emphasizes student achievement and, in Nick's words, creates an "idealistic picture of a classroom as a place where people meet and interact." Lowe (1987, p. 90) recalled "seesawing between real terror" during tasks and "tremendous gratitude" over teacher praise, and similarly, Alex tries through constant feedback to afford students positive feelings that they can make some kind of progress and thereby build on success. Nick's image came from his Japanese class, where he learned to view the classroom as a place where it is recognized that learning will flourish in a nonthreatening social context while students have their own worlds which need to be tapped into to make learning meaningful. From the student's viewpoint, he suggests that without interaction "you might as well have a tape recorder or listen to the radio or something." Therefore, he tries to encourage interaction, which he attributed to his Japanese teachers being female; so his "atmosphere" is now what he calls more "girly," or warm, cooperative, and supportive in the light of tensions he often felt. 


\section{Positive Influences of LLE on Participants' Teaching of English}

McDonough (2002) shows that many activities currently unpopular in communicative language teaching such as grammar exercises, reading aloud, or translation are often popular with learners. From a teaching perspective, it is "important to get under the skin of learner preferences" (p. 409), and participants' experiences show that activities unpopular in the communicative ethos of ELT are seen by them and their classmates as being popular. Such realizations avoid both "a pedagogical ritual" and "a faithful following of routines" (Prabhu, 1990, p. 171). Reflecting on their learning, three of the participants pointed to mechanical teaching as beneficial for learning, suggesting that their classroom experience can feed back and enrich their received knowledge: facts, theories, and related specialized knowledge gained from research. This is similar to what Prabhu calls a "sense of plausibility" (p. 172) in teaching which is engaged when teachers conceptualize their teaching. This is based on earlier experiences of teaching and learning encouraging a constant questioning of practice to avoid an adherence to a fixed method.

\section{Memorization and Drills}

Constant questioning of practice can lead to teachers adapting and building on experiences. While as a learner Alex benefited from mechanical drilling of collocations and infinitive verb forms, he feels the "communicative syllabus" has been "thrust" on him through an insistence on one 90-minute class a week. He sees "conversation" classes as the "cherry on the top" of the "base" of high school education, which stressed learning vocabulary and grammar, but feels this base becomes neglected in university classes. As such, Alex and others would like to encourage memorization techniques in their teaching repertoire; Alex suggested that in his English classes "there are all sorts of area[s] that need redoing" and would like to encourage activities practiced in his Japanese classes, where he memorized transitive and intransitive verbs and polite forms in Japanese. Alex recalls telling his students how he found memorizing vocabulary beneficial for reinforcing language in his learning so he tries getting students to make word cards and carry vocabulary notebooks where possible as he thinks that word cards "are an extremely effective way of learning" that goes beyond translation, where vocabulary is often not recycled. Similarly, John liked word substitution practice as it forced him to use a pattern which "sticks in your head and does work" while Bill, Tom, and Ian valued learning patterns from a textbook. Bill feels that 
the "vast step" of making one's own sentences from pattern practice was very beneficial for understanding the limitations of phrases and collocations, as the teacher would point out where certain usages were inappropriate due to "interference" from English or lexical restrictions.

The participants feel constrained by an emphasis on communicative "conversation" in English classes at their university, which in their view too narrowly defines what teachers should do in the classroom. Nick and Bill felt they ought to reteach students basic language because, despite grammatical knowledge, students find forming expressions really difficult. As a student, Bill enjoyed mechanical sentence composition with his classmates with the sentences being read aloud in turn, the teacher pointing out situational appropriateness and lexical restrictions. During the interview he said he was still searching for a way to include this in his classes, but feels the exigencies of class size preclude such an approach. Bill had to "teach them language, basically" drawing on his experience because, despite grammatical knowledge, his students find forming expressions really difficult. Tom realized that he needs "no end of" repetition to understand grammar rules, for pronunciation practice, or to hear model answers. Acknowledging that though that may be boring for him as a teacher, he likes to give space and additional time to his students. Without personal FL learning experience, he feels that he would probably go a lot faster, thus not allowing students to digest lesson content.

\section{The Teaching Approach}

Lamb (1995) says that engaging with new ideas and accommodating them into belief structures is crucial for changes in practice. Nick, for example, said he tries to exploit language by looking at the elements of a word, based on how the teacher spent time on classroom learning of kanji characters. He recalled how the word "exotic" came up in a class and felt that in the same way that kanji are made up of elements, if one treats "exotic" as a "language element" then "exotic people," "exotic food," "exotic travels," collocate with it. Since then, he has tried to take one small piece of language and generate useful word compounds, similar to his study of a single kanji.

John has been strongly influenced in the way he teaches as his Japanese study in Australia was based on the principle of something being reported at the end of an activity where the teachers were focusing on the students' product as a way of ensuring task persistence during the process. As John sees many students in Japan as being reluctant learners, 
he always has students produce a product at the end of an activity: "Often kids don't want to be there so I've always had a product at the end; otherwise they wouldn't do the activity and the classes are so large that I couldn't check on them." Although he considers himself a poor learner, he says listening, repeating, and substitutions encourage him because "it didn't matter about my motivation as I had to produce." Reflecting on the transcript of the interview, John suggests he plans to use more activities of the same nature in the future.

\section{Regularity of Class Structures}

McDonough (2002) recalled her students appreciating regular practice and similarly John now applies the same formula for every one-hour class as a result of his "good study" while learning; he checks homework, performs listening and repeating activities followed by substitution drills, and then at the end uses 15 minutes where students put their books away to encourage free conversation. As such, each class would have a structure, which John feels is almost like a martial arts class:

The students know exactly what will happen each time and I like that. It's made it very comfortable. And very useful because at each stage you know what they're doing. I can see the methodology in that and what they are trying to address and I also know that I've had my listening skills tested and my homework tested. If the students know the system it saves a lot of wasted time. I know [what] we're going to do at every stage and I could be ready for that and I could concentrate on the activity.

Tom also liked having routines or daily assignments similar to elementary school students who read a page a day from an assigned text. He found that the regularity of doing tasks at night, which were then checked the next morning, seemed to help his learning. The routine was enjoyable and frequent checking made him aware of progress. John did not like the incongruity of much communicative language teaching as he says students like to know what's happening, and so being explicit about task rationale is preferable to an inductive approach. While admitting the difficulty of doing so on a regular basis, Tom tried to make a point of giving students detailed feedback as to their progress as part of the midterm test. He said he tries to have one part of the test be accuracy-based so the learners can see what they know at that level and since he liked getting feedback in his Japanese class, he imagines that students similarly appreciate getting some exact feedback. Bill also appreciated individualist approaches so he 
now tries to get to know his students during pair work or group work activities by listening in on conversations and asking pertinent questions. He states that he is genuinely interested in them as people and is very keen on establishing rapport.

\section{Using the Students' Mother Tongue}

Nick and John saw teachers using only English as "short-circuiting" language learning processes, Nick recalling with gratitude when teachers insightfully explained key points in English during Japanese class instead of "pantomiming and gesturing." While Nick does not do a lot of grammar presentations to the whole group due to a lack of confidence, he often does a quick translation of a point as a timesaving strategy. John thought that task instruction should be in Japanese as the metalanguage of the task is often more complicated than the activity itself. He never felt "ripped off or gypped" when his Japanese teacher explained in English so he now encourages on-task code-switching to aid comprehension: "That's much more important than getting started and realizing that some of the kids haven't got it." He often gets the more able students to explain tasks as "it's so critical that they get off to a good start." Conflicts between participants' experienced knowledge and received academic knowledge have led to tensions or "divergences among different forces or elements in the teacher's understanding of the school context [and] the subject matter" (Freeman, 1993, p. 488). The participants' insights that mechanical learning can be beneficial echoes Rivers' (1983) tensions as she realized that repeating after tapes to get correct intonation and pronunciation was actually contrary to her own received knowledge of communicative learning which she espoused in her "practical guides" to other teachers.

\section{Negative Experiences of LLE Which Enhance Teacher Knowledge}

Participants also recalled negative experiences originating from impatient, unsympathetic, or intolerant teachers. This can help to reinforce their models of successful teaching and make teachers who invest effort into making learning interesting stand out.

\section{Lack of Flexibility}

While Pat acknowledged the huge influence that his Japanese learning experience in college in America had on him, it also made him realize the pitfalls of being inflexibly set on one teaching method: 
The way I learned which I now know as the Audio-Lingual Method and was a lot of repeating, trying to get perfect pronunciation and I really didn't agree with that method. So when I became a teacher I didn't do anything like that and when I got my Master's degree I learned what it was and I was never going to do anything like that in any of my classes.

He learned a lot of set phrases but if the situation did not apply, he felt he could not utilize the knowledge:

I really hated it. I wanted to come to Japan, I wanted to learn Japanese very much, I was very motivated but I hated the study. I studied a lot but I still couldn't do it and now I understand the Japanese style of "only teaching THIS way is OK and not THIS way." I'm not big on repeating, or setting only one answer as being OK; I'm very much involved in building fluency. And in the book they have set questions so I never do those. Same type of thing I had to do in Japanese class. I don't do anything like that.

He recalled the complete inflexibility, and while comprehending the rationale, he now takes an opposite approach, emphasizing student effort and explorations with language rather than concentrating on final output. Calderhead and Robson (1991, p. 3) suggest it is useful to reflect on "episodic memories" which relate to "particular significant events" including negative influences and Pat's approach is very much a direct reaction to that type of teaching. He thought that if learners show effort, turn in their work, and are trying to learn the language, they deserve good grades.

\section{Frustration Over Inappropriate Teaching Styles}

Nick, Alex, and Bill recalled frustration over teaching style looking from a learner's bottom-up perspective of classroom events instead of from a teacher's top-down planning perspective (McDonough, 2002). While participants enjoyed mechanical aspects of learning as noted earlier, they also recalled activities which to them made poor use of class time. Nick reflected on two very negative experiences, one involving chain drilling and the other a self-introduction, which have influenced his approach. In one Japanese class of about 40 students, the first students in the chain would "go out of their mind with boredom" while the subsequent students performed an essentially meaningless activity. Also, in another class, he remembered waiting his turn to perform a self-introduction as his first experience in a new class, noting that "I don't think I've been in 
a more stressful language environment." Nick now avoids "putting students on the spot" where they are unsure of teacher or class expectations. He encourages a personalized, more intimate "affective" class through small group work whereby individual students are not the center of attention, but support each other. Nick found chain drilling and choral practice to be an "unbelievably boring experience" and lacked structure; he stated that his teachers used them basically because they "didn't know how to teach." He suggests teachers search for activities to "make the class go relatively easily" despite evident student restlessness. As this study seems to suggest, teachers who constantly question the goals, values, context, and assumptions are engaged in reflection (Zeichner \& Liston, 1996), but our participants here suggest that their own teachers had often been preoccupied with technique, which is understandable as teachers have a tendency to maintain the methodological status quo (Lamie, 2000). Nick felt Japanese teachers often try to make up for a lack of training by "making tons of worksheets," while Bill suggested that his teachers thought that "all you needed to do was to find the right things to put in front of the students," but he realized through learning Japanese that successful teaching involves more than material selection in that students need to know the rationale and outcomes expected without being flooded with language data. As an example, Bill, Nick, Alex, and John all suggested lessons often become explanations in Japanese about Japanese. Alex recalled the "grind," while Nick's classes had revolved around reading aloud, repetition, and extensive explanation of points of grammar using the blackboard without realia or situational practice. After their reflection, they now emphasize language input, intensive practice, and helping students to "navigate through the confusion" as Alex puts it. Going to Japanese lessons has made Nick think about how to present language to reduce frustration. He suggests good teachers are "distinguished from average ones by their ability to explain simply and clearly" as students are able to understand why they are studying, what they are studying, and the outcomes the teacher expects rather than studying language for the sake of studying language.

\section{Images Participants Hold of Their Japanese Teachers}

\section{Positive Images of Teachers}

Positive images reinforce the appropriateness of the teaching model, with Bill holding images of "motherly, conscientious teachers" who were "caring for the students and very kind and helped us along." He recalls 
fondly one teacher who was genuinely interested in him and who helped him overcome the "confusion and frustration" at the start of learning, so he now tries to listen in and participate during pair or group work in order to foster rapport and encouragement by trying to see his students as a collection of unique individuals. Nick recalled a teacher who was "amazingly" conscientious and did "tons of things" that "must have taken her hours to do" recalling her "willingness to go so far to help her students." He remains impressed that the teacher showed that kind of attention to detail and believes her conscientiousness has influenced his teaching:

I've had large writing classes, and I've crazily spent hours marking, making tapes for students about their work and it's fine for a class of 5 or 10 or so but when you've got 40 , it takes you weeks to do it. Students have come back to me and they're astonished at the sort of input I've given them and I think it affects them. I think a lot of Japanese teachers do work hard and they're very conscientious and I like that.

Recalling, adapting, and manipulating images of either influential teachers or, conversely, poor role models is an important aspect of teaching knowledge (Calderhead \& Robson, 1991, p. 3), and Tom's image was that of a calm, controlled, and assured teacher as he had had. She had a passion about the language and it was very clear that she loved Japan and was animated in her teaching but never "got short-tempered and seemed very even-keeled." As he is sure that all the students admired her approach, he now tries to emulate her in his manner towards students.

\section{Negative Images of Teachers}

As knowledge is in part experiential and constructed by teachers themselves, even negative experiences can "open windows of possibilities" (Golombek, 1998, p. 447). Nick recalled some surly teachers who have a definite attitude of "you're not welcome; you're making extra problems for me" and others who come across as having the attitude that the ideal number of students would be "zero." Based on this he now sees personality as being very important. Alex, Nick, and Pat all held negative images of teachers of Japanese who in their different ways have had what it would not be an exaggeration to regard as traumatic effects on their careers as English teachers. In three different conversations with Alex, he revealed a recurring image that has unquestionably affected his approach to teaching. He felt that being outspoken and too forthright in his opinions in class, although in Japanese, were seen by the teacher as 
somehow being unfavorable to Japan. The result of this friction was other students being allocated his turn, and his not being called upon to read aloud in class. He perceived his class not so much as about learning the Japanese language, as being taught to "Go away and be happy in Japan." For Alex, this incident was critical:

Honestly, I think the most important thing I learned was that negative example of not listening to the students and I really feel that the ability to listen and not to impose my own values and opinions to the student is something that is very important and very, very, very, valuable because you can have any number of lesson plans but if you don't listen to the students then what is going to happen?

From those experiences, Alex now says he feels that when students are sharing their opinions, he must not tell them what to think, must be appreciative of all students' contributions in the target language, and must listen to them while constantly reminding himself to listen patiently even when he finds himself wanting to express disagreement at once.

Pat held an ingrained image of one of his Japanese teachers while studying Japanese as part of his minor in college in America. In the interview, he mimicked her finger-wagging and facial mannerisms. The teacher, who he said was "very famous," had written the class text, believing "wholeheartedly" in her method. In each class, students would get points for pronunciation with a score of four "being almost fluent." He says:

Well, partly because if you mispronounced a word, your grade would go down one point which means that if you mispronounce a word you get a 75\% for the class and I had a problem with " ra ri ru re ro" which still isn't perfect after all these years, and I knew that every time I had to utter any of these sounds in a set conversation I would lose points.

Although he complained, and worked with his teacher to improve his pronunciation, he was not successful. He explains, “But I just couldn't do it. And my grades were always really bad like AAC or AAD or something. It really bothered me. That kind of inflexibility is what I really remember." He stated that his low grade point average in class would probably have affected his chances of postgraduate study in America. He remembered the same teacher chastising him for deviating from a fixed pattern during conversation practice. He recalled how the teacher would clap her hands 
in annoyance and glare: "There was no room for anything. Even if it was good Japanese, I couldn't do that." While Pat's English classes do have a structure, there is a flexibility to encourage student experimentation with language and the production of their own dialogues without patterned texts.

Nick's negative experience occurred in his childhood. Although this was not an experience of studying Japanese, Nick insisted that this episode was "fundamental" to his teaching and was "seared into his consciousness."

The teacher just took the piss out of everybody and if you didn't get it right you were like a worm and he'd just make you feel awful. So awful. And that really affected me. I hated him and I hated French and I hated foreign languages. It still rankles.

Nick recalled a school sports day when the French teacher met Nick's father and proceeded to ridicule him in front of his father about his French pronunciation, which his father thought amusing but which Nick found humiliating. Teachers' recounting of experience with one another encourages insight into affect and the moral dimensions of how learners should be treated. This is seen in Nick's case as he now tries "so hard" to be kind and supportive because of that experience which is so "deep."

\section{Implications}

This study has shown that teachers had grown more empathetic to learners, more engaged to their students and more receptive to new ideas through their formal study of Japanese. Nick saw the "definite benefit" of looking at classrooms from different perspectives and now as a result of his classroom learning encourages teachers to visit each other's classes. Doing so challenges entrenched methods and perhaps even gives rise to a realization that "you might have been doing something fundamentally wrong for so many years." Bill suggested that Japanese study had helped him "revamp" his syllabus while others stated that their Japanese classes had helped them become more aware of different individual learning styles and how learners invest their own beliefs in tasks (Donato, 2000). Instead of being set on any one "communicative" method or approach, the participants through their learning experiences say they are more openminded about activities such as the use of repetition and drilling and using Japanese in English class, which some teachers may find counter to communicative approaches. Participants found "a one-size-fits-all, cook- 
ie-cutter approach" (Kumaravadivelu, 2003, p. 23), to methods contrary to their teaching styles, and so encourage a flexible and open-minded approach to teaching. They eschew fixed teaching styles and keep students informed both of the purpose for an activity and learning outcomes so that students can adapt tasks to their own preferred learning styles.

Bill suggested that classroom learning experiences changed his "conceptions" of teaching. Experience encouraged a "sort of germination process" where teaching was improved by reflecting on practice. This coincides with Lamb's (1995, p. 77) view that teachers engage with new ideas which they "accommodate within their belief structures" by changing or adjusting previously held beliefs leading to the introduction of new ideas while encouraging doubts about current practice. This flexibility means that personal and public theories become "living, intertwining tendrils of knowledge which grow from and feed into practice" (Griffiths \& Tann, 1992, p. 709), which has implications for how teaching has come to be evaluated in Japanese tertiary education. The participants in the study have reflected on their concrete experiences of learning a foreign language, which has led to conceptualizations and experimentations in their teaching where the concepts of teaching thus gained are tried out in their respective situations. Because reflection is an intrapersonal process, it can both be a method of informing practice and promote changes in behaviour and practice.

\section{Conclusion}

All of the teachers in this small study have shown how their experiential knowledge of learning Japanese and the images, both good and bad, of teachers have filtered their learning experience so they can reconstruct knowledge and respond to the exigencies of their unique teaching situations. Teacher learning is "dependent on bringing to consciousness and examining the assumptions and considerations which make sense of their actions as teachers" (McIntyre, 1993, p. 43), so significant change can only occur if teachers are engaged in personal exploration, experimentation, and reflection. Through sharing classroom stories while reflecting on experiences they can learn about the affective consequences of their teaching practice (Golombek, 1998). Teaching knowledge may be present in our thoughts waiting to be used. The purpose of reflection, ultimately, is to engage teachers, to encourage and sustain them in a process of change. 


\section{Acknowledgements}

I would like to thank the anonymous reviewers and in particular the editor, Steve Cornwell for their help and many insightful comments and advice.

Peter Burden is an associate professor at Okayama Shoka University. His particular research interests include student and teacher beliefs and the use of students' mother tongue in conversation classes.

\section{References}

Brandt, C. (2007). Giving reflection a voice: A strategy for self-evaluation and assessment in TESOL teacher preparation. In C. Coombe, M. Al-Hamly, P. Davidson, \& S. Troudi (Eds.), Evaluating teacher effectiveness in ESL/EFL contexts (pp. 199-213). Ann Arbor: Michigan University Press.

Brown, J. (1995). The elements of language curriculum. Boston: Heinle and Heinle.

Calderhead, C., \& Robson, R. (1991). Images of teaching: Student teachers' early conceptions of classroom practice. Teaching and Teacher Education, 7 (1), 1-8.

Clandinin, D., \& Connelly, F. (1987). Teachers' personal knowledge: What counts as personal in studies of the personal. Journal of Curriculum Studies, 19 (6) 487501.

Cooper, P., \& McIntyre, D. (1996). Effective teaching and learning. Buckingham, UK: Open University Press.

Dewey, J. (1933). How we think: A restatement of the relation of reflective thinking to the educative process. Boston: D. C. Heath.

Donato, R. (2000). Sociocultural contributions to understanding the foreign and second language classroom. In J. Lantolf (Ed.), Sociocultural theory and second language learning (pp. 27-51). Oxford: Oxford University Press.

Elbaz, F. (1981). The teacher's "practical knowledge": Report of a case study. Curriculum Inquiry, 11 (1), 43-71.

Eraut, M. (1994). The acquisition and use of educational theory by beginning teachers. In G. Harvard \& P. Hodkinson (Eds.), Action and reflection in teacher education (pp. 69-88). Westport, CT: Ablex Publishing.

Flowerdew, J. (1998). Language learning experience in L2 teacher education. TESOL Quarterly, 32 (3), 529-536.

Freeman, D. (1993). Renaming experience/reconstructing practice: Developing new understandings of teaching. Teaching and Teacher Education, 9 (5/6), 485497.

Golebiowska, A. (1985). Once a teacher, always a teacher. ELT Journal, 39 (4), 274279.

Golombek, P. (1998). A study of language teachers' personal practical knowledge. TESOL Quarterly, 32 (3), 447-464. 
Griffiths, M., \& Tann, S. (1992). Using reflective practice to link personal and public theories. Journal of Education for Teaching, 18 (1), 69-85.

Harrington, H. (1994). Teaching and knowledge. Journal of Teacher Education, 45 (3), 190-198.

Hegarty, S. (2000). Teaching as a knowledge-based activity. Oxford Review of Education, 26 (3 \& 4), 451-466.

Kumaravadivelu, B. (2003). Beyond methods. New Haven: Yale University Press.

Kumaravadivelu, B. (2006). TESOL methods: Changing tracks, challenging trends. TESOL Quarterly, 40 (1), 59-81.

Lamb, M. (1995). The consequences of INSET. ELT Journal, 49 (1), 72-80.

Lamie, J. (2000). Teachers of English in Japan: Professional development and training at a crossroads. JALT Journal, 22 (1), 27-45.

Lincoln, Y., \& Guba, E. (1985). Naturalistic inquiry. Newbury Park, CA: Sage.

Lortie, D. (1975). School teacher: A sociological study. Chicago: University of Chicago Press.

Lowe, T. (1987). An experiment in role reversal: Teachers as language learners. ELT Journal, 41 (2), 89-96.

McDonough, J. (2002). The teacher as language learner: Worlds of difference? ELT Journal, 56 (4), 404-411.

McIntyre, D. (1993). Theory, theorizing, and reflection in initial teacher education. InJ. Calderhead \& P. Gates (Eds.), Conceptualizing reflection in teacher development (pp. 39-51). London: The Falmer Press.

Nespor, J. (1987). The role of beliefs in the practice of teaching. Journal of Curriculum Studies, 19 (4), 317-328.

Prabhu, N. (1990). There is no best method-why? TESOL Quarterly, 24 (2), 161176.

Ransdell, D. (1993). Creative writing is Greek to me: The continuing education of a language teacher. ELT Journal, 47 (1), 40-45.

Richards, J., \& Lockhart, C. (1994). Reflective teaching in second language classrooms. Cambridge: Cambridge University Press.

Rivers, W. (1983). Communicating naturally in a second language. Cambridge: Cambridge University Press.

Schön, D. (1983). The reflective practitioner: How professionals think in action. New York: Basic Books.

Thornbury, S. (1991). Watching the whites of their eyes: the use of teachingpractice logs. ELT Journal, 45 (2), 140-146.

Wallace, M. (1991). Training foreign language teachers: A reflective approach. Cambridge: Cambridge University Press.

Waters, A., Sunderland, J., Bray, T., \& Allwright, J. (1990). Getting the best out of "the language learning experience." ELT Journal, 44 (4), 305-315.

Wellington, J. (2000). Educational research: Contemporary issues and practical approaches. London: Continuum. 
Williams, M. (1999). Learning teaching: A social constructivist approach-Theory and practice or theory with practice? In H. Trappes-Lomax \& I. McGrath (Eds.), Theory in language teacher education (pp. 11-21). Harlow: Longman.

Wolcott, H. (1994). Transforming qualitative data. Thousand Oaks, CA: Sage.

Zeichner, K., \& Liston, D. (1996). Reflective teaching. Mahwah, NJ: Lawrence Erlbaum.

\section{Appendix}

\section{The Participants}

\section{Bill}

Bill, who is writing up his doctoral thesis, has studied Japanese formally intermittently over a number of years. His last classroom experience was in the fall semester of 2006. He acknowledges some influence of his Japanese language classroom experience on his way of teaching, and as he views his current teaching as going through a "transitional phase," he states that reflecting on his learning experience is one way of trying to get a better balance between language from students and language in terms of input.

\section{Nick}

Nick first came to Japan in 1984. After starting a new job after finishing his doctorate he sat in on a Japanese class for overseas students in the University but found the teaching methods frustrating. He says that studying a foreign language while teaching has increased his empathy for both teachers and students.

\section{Alex}

Alex successfully learned French in Montreal and later Spanish by immersion while working on a ranch in South America. He stopped Japanese classes abruptly about 5 years ago after a classroom experience which led him to question both his values and the way he treats his students. While he says that the learning of Japanese has influenced his teaching to a degree, he feels that intensive teacher training courses such as CELTA and DELTA and his postgraduate degree study, which "has lots of theory," tend to "swamp over everything." 


\section{Tom}

Tom first learned Japanese at a community college in Hawaii for a semester. He states that his master's degree in TESOL, which included a residential requirement and frequent supervision of teaching practice, has been a big influence on his practice. He feels himself to be a poor classroom learner, saying that this increases his admiration for his students and encourages a sympathetic classroom teaching approach.

\section{Pat}

Pat has had extensive classroom learning of Japanese as a "minor" subject of his undergraduate degree in International Relations in the U.S.A. He studied Japanese every day, three trimesters a year, for 3 years and says that his teaching approach is directly influenced by his Japanese learning experience. When he got his master's degree he vowed he would never teach like his Japanese teachers.

\section{John}

John first started learning Japanese when as an external student he would go back to Australia twice a year for one-week courses to practise Japanese as a part of his undergraduate degree in Asian studies. He elected to study Japanese as an "easy credit" as he was living in Japan. He describes his level as "poor" and himself as a "hopeless" learner, which he relates to "motivation and laziness." However, because he found himself learning "quite a bit" despite himself in his Japanese classes, he feels this has influenced his teaching especially as he sees Japanese students as lacking interest in English. 
